\title{
INVESTMENT OF HUMAN CAPITAL IN TOURISM AND HOSPITALITY WITH A SPECIFIC REFERENCE OF R.MACEDONIA
}

\begin{abstract}
MSc. Snezana Bardarova, Faculty of tourism and business logistic-Gevgelija, University Goce Delcev, 2000 Stip, Republic of Macedonia

PhD. Zlatko Jakovlev, Faculty of tourism and business logistic-Gevgelija, University Goce Delcev, 2000 Stip, Republic of Macedonia

PhD. Cane Koteski, Faculty of tourism and business logistic-Gevgelija, University Goce Delcev, 2000 Stip,
\end{abstract} Republic of Macedonia

Mob.phone: 0038978444294

e-mail: snezana.bardarova@ugd.edu.mk

\begin{abstract}
:
The fact that today tourism takes a bigger swing in the share of GDP, has prompted firms from the tourism sector to take measures to invest in their business. Thus, given the numerous studies proved that today tourism take a greater participation in the economy and hence the performance and creation of profit in tourism lies in more employees, unlike in the past when equity is created in the area of money and materiel. Today, the capital of every enterprise representing people with their knowledge, professionally, experience, creative ideas and potentials. So investing in a professional and qualified staff is the key to successful and profitable operation of tourism and catering companies. The subject of this research paper are companies from the tourism sector in $\mathrm{R}$. Macedonia and how they invest in human capital.
\end{abstract}

Keywords: human capital, tourism, investment, employment, skills.

\section{Introduction:}

The tourism and hospitality sector includes companies that directly realize the majority of its revenue from the consumption of tourists, for example, facilities that offer:

-Short term accommodation (hotels, motels, apartments, etc.)

-Food and beverages (restaurants, catering facilities, markets);

- Leisure and entertainment (various tourist attractions and leisure activities) and companies offering

- Travel and transport services (travel agencies, rental cars, etc.).

In addition, this sector includes other types of 74 businesses, such as construction companies, manufacturing, retailing and services. These economic activities do not generate revenue directly from the spending of tourists, but supply companies that provide services directly to tourists. Strong tourism links created with other sectors of the economy by paying attention to the multiple effects of tourism consumption is widely recognized. Tourism as a service industry taking a bigger swing, his progress is vital for the development of the economy. Today, more attention is paid to this branch, because it became the most important productive sector in terms of contribution to gross domestic product (GDP), in terms of providing employment and in terms of the provision of foreign exchange earnings. Through tourism are creating added values in other economic sectors that are somehow related to tourist enterprises. Tourism also serves as a catalyst for development in other areas of the economy, including ancillary services and infrastructure. In addition, tourism often has provided communities and economic rationale for the protection and preservation of cultural heritage and culture and to improve product and service, especially in the services related to the food industry. Tourism as a major industry that encompasses many different types of tourist facilities that are dealing with tourism and catering industry employs different and numerous staff work. As such, this branch is very widespread and it is noticed significant growth of its share in the budget. Tourism is an important sector for employment as it provides a number of 
different jobs. Considering the fact that today the capital of tourism in general to create employees, that they are a key factor for visiting the tourist and catering facilities it's necessary to provide the human capital investment in tourism in order to maintain economic stability of the enterprise and hence the national economy.

\section{Human Capital}

Human capital is not represented only by people in the organization but also what these people wear and contribute to the success of the organization. Human capital is the collective value of the capabilities, knowledge, skills, life experiences and motivation of the workforce of the organization. ${ }^{1}$ In modern economic analysis term human capital is defined as a set of production skills, talent and knowledge of the individual, acquired through: education, scientific research, job training and experience. Human capital in the touristcatering establishments represent human's i.e. people who are employed in enterprises that are engaged in providing and performing services (managers, waiters, receptionists, bartenders, etc.). Human capital is the decisive factor for success in the market conditions in all areas. It is of great importance for achieving the strategic goals of the firms. The successful operation of firms in general depends on the successful management of human capital, i.e. the ability of the firms to manage the talent or the human capital. The term human capital describes the economic value of the knowledge, skills and capabilities of staff. Although their value may not directly affect the balance sheet of the firms, though its economic impact plays a significant role in the operation of firms. In economic theory, human capital is analyzed from two aspects, namely: the microeconomic aspect, which basically explores the impact of the amount of human capital on earnings of individuals, and the macroeconomic perspective, where emphasis is placed on the contribution of human capital on economic development.
In terms of a functioning market economy, one in the economic analysis is treated as a consumer and as a producer. As a consumer it determines production, and thus the nature and pace of economic development. Being the manufacturer, it directly affects productivity growth. The concept of human capital allows investment in human resources to be treated the same as investments in any other activity or as capital have its price and its rate of ROI. Human capital is increased through training and education on human resources, thereby increasing its contribution to economic development.

\section{Analysis of the situation of workers in the tourism sector in Republic of Macedonia}

Human capital is consists of people with their knowledge, which is regarded as the intellectual ownership of the individual who has a price on the labor market. Today, human capital raises high on the pedestal of the factors for the prosperity of tourism and hospitality entities, on whose basis persists the market economy.

Increasing and improving the skills of the employees have the greatest impact on economic growth. Human capital increases in the education system, thereby increasing its contribution to economic development. For the survival of the tourism business market it is necessary to invest in human capital. According to data from the State Statistical Office of Macedonia, approximately $3.5 \%$ of the labor force and more than 20,000 people work in tourism and hospitality sector. The hotels and restaurants account for a large proportion - more than $90 \%$ of total employment in the tourism sector. Table 1 below shows the total labor force and the number of employees in the tourism sector, Report 2007.

\footnotetext{
${ }^{1}$ (Matis L. R et al 2012), "Management of human Resources", p.5
} 
(JPMNT) Journal of Process Management - New Technologies, International

Vol. 1, No.4, 2013.

Table 1: Number of employees in the tourism sector in 2007

\begin{tabular}{lll}
\hline Employees & Number & Percent \\
Total & 590,234 & 100 \\
$\begin{array}{l}\text { Hotels and } \\
\text { restaurants }\end{array}$ & 18,995 & 3.22 \\
$\begin{array}{l}\text { Travel agency and } \\
\text { tour operator }\end{array}$ & $1.230^{*}$ & $0,22^{*}$ \\
\hline & & \\
\hline Source: State Statistical Office of R. Macedonia and ATAM
\end{tabular}

In recent years, the increasing trend of employment in hotels and restaurants is more than obvious, as can be seen from Table 2 below, especially in 2006, when the number of employees increased by about $50 \%$ compared with 2005. The data since 2007, although significantly lower than those in 2006, should be considered for consolidation dramatic increase from previous years.

Table 2: General trend of employment in hotels and restaurants-2004-2007

\begin{tabular}{lcccc}
\hline Employees & $\mathbf{2 0 0 4}$ & $\mathbf{2 0 0 5}$ & $\mathbf{2 0 0 6}$ & $\mathbf{2 0 0 7}$ \\
& & & & \\
$\begin{array}{l}\text { Hotels/ } \\
\text { restaurant }\end{array}$ & 12.672 & 13.558 & 19.034 & 18,995 \\
\hline
\end{tabular}

Source: State Statistical Office of R. Macedonia and ATAM

The Hotel Association of Macedonia (HOTAM) said that the total number of employees in hotels and restaurants is around 50,000 . Besides the 20,000 official employees, according to the association, an additional 15,000 unregistered workers (most of them full-time) and 15,000 workers call (free occasional workers) are active as tourist workers. The difference between official state statistics and information from professional association is very large ${ }^{2}$. Based on the research conducted in the state of employment

\footnotetext{
${ }^{2}$ Government for the development of tourism in Macedonia, 'National Strategy for Human Resources Development in Tourism 2009-2013' 76
}

in tourism in the Republic of Macedonia it has seen the necessity of hiring professional and skilled staff, for which until now our managers of tourist facilities were ignorant and poorly informed. Given this rate of employment in the tourism sector and its role in economic development, on the one hand and the role of the human factor on the growth of earnings of tourism enterprises, it is clear that it is more than necessary to invest in human capital. The fact that the human factor is an important requirement for attracting tourists leads to the conclusion that tourism and catering firms to achieve the desired goal cannot employ any staff, professional staff, but they most to invest 
in it to stay competitive on the market of tourism and hospitality service. This opinion is confirmed by the position of L. Platt, HewlettPackard, that (Successful companies of the 21 st century will be those that perform the best job in capturing, storing and expanding the knowledge of their employees).

\section{Forms of investment in human capital in tourism}

Investments are a necessity, because the future development of any organization is linked to good planning and effective realization of investments. There are a number of different definitions of investment terms and investment $^{3}$, although there is no general agreement about the definition of investment, but most authors agree that: investments, i.e investment are submitting victims, denial of consumption in the present in order to receive certain benefits in the future. P. Masse gives a general definition that (an investment exchange and some immediate satisfaction which it differs by the hope that man gets that underpin investment well). Victims who have filed the present and profits or revenues, which are expected in the future, constitute one of the basic characteristics of the investment process and investment. Under most investment means investment of funds in the creation of a good product ${ }^{4}$.

In the economic literature, there is a consensus that investment in human capital is made by education and training and they are important for any firm to ensure its success in a changing and intensely competitive environment. It is also argued that this importance is particularly high in the tourism and hospitality industry, where the quality of service continues to be the most important characteristic differentiating a

\footnotetext{
${ }^{3}$ H. Peumars gave definition: "The investment includes the purchase of real goods, which will tell the payment of a current cost to the future has a certain income. It means something is sharing some hopes for array deployed at the time ".

4 According to P. Masseu: "The investment in common terminology, means at the same time and work and the result of that work, and at the same time and investment decision and invested well."
}

company or a destination from its competitors. Investing in human capital in tourism enterprises is achieved by investing in the education of human resources. It is essential that investment in human capital is achieved through hiring competent workers for the particular job opportunities for training for work in progress. To facilitate investment in human capital needed for the company to have funds to be able to offset the cost of training and education of human resources through that build intellectual capital who has the basic importance of tourism enterprises working. By investing in human capital despite the benefits it has only companies which are expressed through the income statement, on the other hand, motivates employees to work better. Hence, the necessity for the successful operation of businesses in the tourism and hospitality is employment and investment in professional staff that loves their job and would accept to educate and upgrades.

Education is one of the ways through which human capital-gains knowledge, and is a form that creates services that have value to the economy. Investing in education is an activity that causes an increase in knowledge, skills and abilities of individuals, or an increase of their productivity. For knowledge as a form of human capital, the famous American economist and Nobel laureate Theodore W. Schullz, believes that (education is the 'human' as an integral part of man and that is capital as a source of future satisfaction, revenue and earnings). Knowledge acquired denied proper education can be defined narrowly and broadly. In the narrow sense, knowledge is defined as capital that is acquired in educational institutions, and this type of education is known as formal or regular education. While in a broad sense knowledge despite the formal and non-formal education covers or acquired knowledge that is not tied to educational institutions. Education has sided impact on economic and human development. Proceeds from investments in knowledge, i.e. in human capital are far greater than those provided by physical capital. In explaining the growth of GDP has been proven that the accumulation of human capital is three to four times more important than the accumulation of 
unskilled labor, while the growth of total factor productivity is strongly determined by the initial level of human capital.

Human capital except through formal education can be acquired through on the job training (informal education). Training and improvement aimed at increasing the capabilities and skills of employees in order to give a greater contribution to increased productivity and performance goals of the enterprise. Staff training mostly is in terms of promotion of employees to master several foreign languages, have skill service to customers and to acquire new techniques of behavior. Training is a process that provides, maintain or improve employment or other abilities and skills of employees or management and other capabilities and skills of managers, to achieve, maintain or increase the standard or desired effects in the workplace or a managerial function. Training is a process in which people acquire skills to successfully perform the tasks. ${ }^{5}$ Staff training is carried out according to specific plans and programs, so that when evaluating the effectiveness of training programs, literature clearly indicates that training is an important component for successful operation of tourism enterprises catering to them but must be approached with caution or its objectives must be clearly specified and must develop action plans.

The importance of personal services in the tourism sector, where the customer is directly in contact with the worker (Baumol, 1985), makes it necessary to study some other specific topics such as the relationship between quality of the product International handbook on the economics of tourism and employees' education. Maxwell et al. (2001) and Fleetwood (2002) state that only a properly educated workforce could be able to sustain the high level of friendly, efficient and professional service, which is a major ingredient in ensuring satisfied customers and continued growth. However, labor conditions in the sector are very poor, with low salaries, high rates of turnover, high seasonality, antisocial working hours, a lack of a career path design, and comprising a significant proportion of the informal sector, that make the acquisition of skills and, therefore, the improvement of the final service, difficult (ILO 2001; Maxwell et al. 2001).

\section{Models of Human Capital Management}

Managing human capital in every enterprise implements the management of human resources which is tasked to provide staff to achieve the objectives of the organization. Human Resources is responsible for the organization's relationship to its employees for performance in their work, and the rewards of their labor valorization, performed tasks and responsibilities undertaken and solving problems. "Human Resource Management is a strategic and coherent approach to managing the most valuable resources in an organization - the people working there who individually contribute to the achievement of organizational goals "(Armstrong, 2006:9). Mc Court I Eldridge defines human resource management as the way organizations manage their employees and individuals affect their growth and development (McCourt, 2003:2).

Theory and practice show that it is an extremely effective and useful way of uniting human resources with others in the organization to achieve its goals. A whole strongly depends on people, their minds, knowledge, quality, behavior, socialization, authority, job satisfaction, motivation etc. Human Resources are focused on people, their motivation and job satisfaction. Human resource management system is part of the management of enterprises. Various models of HRM have been developed from time to time by different teams of the researchers. All these models have helped the HR practitioner to effectively manage the human resources. Some

\footnotetext{
5 (Matis L. R et al 2012), "Human Resources", p. 260
} 
of the important models have been discussed as follows ${ }^{6}$ :

\section{- Michigan Model}

The Michigan model (Devanna et al., 1984) focuses on hard HRM. It holds that people should be managed like any other resources and so obtained cheaply, used sparingly, developed and exploited fully. It also emphasized the interrelatedness of HRM activities. According to this model, selection, appraisal, development and rewards were geared towards organizational performance.

\section{- Harvard Model}

The Harvard model (Beer et al.1984) works as a strategic map to guide all managers in their relations with employees and concentrates on the human or soft aspect of HRM. It strives at employee commitment not control. It also works on the premise that employees needed to be congruent, competent and cost effective.

\section{- Warwick Model}

This model was developed by Hendry and Pettigrew (1990) at centre for strategy and change, Warwick University in early 1990s. It emphasizes on analytical approach to HRM. It also recognizes the impact of the role of the personnel functions on the human resource strategy content. The researcher focused their research on mapping the context, identifying the inner (organizational) and external (environmental) context.

\section{- Guest Model}

Guest comparative model (Guest, 1997) works on the premise that a set of integrated HRM practices will result to superior individual and organizational performance. It advocates a significant difference of HRM from PM. It holds that HRM strategies like differentiation, innovation, the focus on Quality and cost reduction will lead to practices like better training, appraisal, selection, rewards, job designs, involvement, and security leading to

\footnotetext{
${ }^{6}$ (Tiwari, P. and Saxena.K 2012) 'Human resource management practices: a comprehensive review', Pakistan business review, pp. 678-679
}

more quality outcomes; commitment and flexibility. It will then affect performance in that productivity will increase; innovation will be achieved as well as limited absences, labor turnover, and conflict or customer complaints.

\section{The role and importance of human capital investment in tourism}

The tourism sector plays an important role in the economic development of many countries. The results in the tourism sector are also important for regional and local development of the country. Effects of the tourism sector are not only economical, but it implicate as social and environmental effects. The positive impact of tourism on the national economy is conditioned by employees. Therefore in order to direct the development of the tourism sector of the country, it is necessary to invest in human capital. Economic development of tourism at the regional level is generally measured by the real value of GDP per capita, although in some cases it should be available in other variables associated with regional per capita income. The role of human capital in addition to the macro level has a major role and the micro level that plays a key role in competition with competition in the market of tourist services. Today tourism enterprises are aware that to survive in the market should require productive and effective business solutions. The fact that the tourism sector is connected with the provision of tourism and hospitality services, leads to the necessity of hiring, recruiting and investing in human resources. This point to the need to develop a capable and flexible workforce in order to compete in the twenty-first century. Investing in human resources is achieved by investing in education through various courses, training programs. These elements of human capital acquired through the education which have a crucial role higher education institutions and associations that take care of the training of human resources. The investment in human capital should ensure that the management of human resources, which should provide finance to cover the cost of investing in human capital. Today, more established organizations that care for the training of human resources. 
However, lack of funding is always the main reason that managers always decide to eliminate the "cost" of investing in the education of employees. Organizations in Macedonia have not yet or rarely sectors for managing human resources. Well, where have rarely found competent person properly completed formal education, made the field research showing that little investment in human potential. Thus, in terms of training, last year, only $42 \%$, or 368 SMEs participated in some training. Total 2,006 employees attended training last year, or the average of any enterprise 5.45 employees participated in training or a total of 26,234 employees, only eight percent participated in training in the last year. The most common reason for this is the lack of sufficient awareness of the usefulness of management training. Those who are dealing with this issue calling training to implement in practical work, and over time and institutionalized or become part of the organizational culture.

\section{Conclusion}

Intellectual capital as a complex economic category is a factor of influence that although insufficient explicitly expressed in traditional strategic planning for future changes, it creates additional value to the organization and has significant long-term impact on future profitability and competitiveness of enterprises.

Establishing system for recognition and validation of empirical competencies of employee's tourism-catering facilities would need a way to ensure the transfer of competencies in organizational systems and outside them, which would allow individual competencies to be transferable across a range of organizational system. Recognizing the complexity of the above problem, further underlines the necessity of developing a model that will include formative evaluation, which supports interaction between competence and their validation, and also initiate and motivate their further development. Methodologies and systems for validation of informally acquired competences play a key role in strategies for turning them into competitive advantage within the organization and outside it. The most important feature of this new approach is to set up a bridge that will assist individuals in combining the results of the acquired knowledge in different contexts, institutions, levels, and even countries, allowing them access to cumulative and documented qualifications and competencies in whole life individual perspective, which recognized and will be recognized evaluate intellectual capital. Successful operation of tourist-catering enterprises depends not only on the number of employees, but also their quality as expressed through their expertise.

The potential of tourism to generate jobs in areas where there are few alternatives for employment and higher impact on the national economy and development resulted in the engagement of the Government for the development of tourism in Macedonia. In this respect she has produced a Strategy for Human Resources Development in Tourism, whose implementation must ensure themselves tourist and catering enterprises and higher authorities. Major role in implementing the strategy for the development of successful business enterprises have a human resources management who must ensure that not only gives orders to carry out the duties of employees, it is necessary to provide a pleasant working atmosphere that will motivate employee to perform work more responsibly and with a desire to progress in work. Hence today, a growing challenge for managers is to get the employees to work better, not what is possible to do. Characteristic for employees in tourism and catering enterprises is that the nature of things that employees in the tourism sector, I deal with the provision of services and there is access to the most important tourist-client, client and how he will be greeted, served and so on. So in practice always satisfied guest returns. The successful operation of these enterprises affects various factors, but the key is the people who work and who are in direct contact with tourists, guests. Therefore employment must be taken care of right selection of staff and became his personal and professional characteristics, and other employer-hotel, restaurant, etc., must provide education, training, training and a strategy for managing them through their employment, 
insurance, regular payment of salary in proportion to the work performed and to find ways to motivate them to work successfully and be able to keep. Hence investing in human capital is an important issue which should be dealt managers tourist catering companies because investment in human capital is the key to profitable and successful operation of these enterprises, on the other hand the successful operation of these enterprises positively influences national Economy of Macedonia.

\section{References}

Baum, T. (1993), 'Collecting and using information about human resources in tourism - the direct survey method', in Tom Baum (ed.), Human Resource Issues in International Tourism, Oxford: Butterworth-Heinemann, pp. 60-76.

Baumol, W.J. (1985), 'Productivity policy and the services sector', in Robert Inman (ed.), Managing the Services Economy. Prospects and Problems, Cambridge: Cambridge University Press, pp. 30117.

Becker, G. (1964), Human Capital, New York: Columbia University Press.

Card, D. (1998), 'The causal effect of education on earnings', in O. Ashenfelter and D. Card (eds),
Handbook of Labor Economics, 3A, Amsterdam: North-Holland; Oxford and New York: Elsevier, pp. 1801-63.

Chung, K.Y. (2000), 'Hotel management curriculum reform based on required competencies of hotel employees and career success in the hotel industry', Tourism Management, 21, pp. 473-87.

Churchward, J. and M. Riley (2002), 'Tourism occupations and education: an exploration study', International Journal of Tourism Research, 4, pp. 77-86.

Matis L. R et al (2012), "Management of human Resources".

Maquieira, R. J, et al, 'Implications of human capital analysis in tourism' International handbook on the economics of tourism, pp. 379-398.

Nickson, D. (2007), 'Human Resource management for the hospitality and tourism industries', Elsevier Ltd.

Kutanis, R. and etc. (2012), 'Investigating hotel employee involvement in strategic human resources management', Tourismos: An International multidisciplinary journal of tourism Volume 7, Number 1, Spring-Summer 2012, pp. 117-134.

Tiwari, P. (2012) 'Human resource management practices: a comprehensive review', Pakistan business review, pp. 669-705, January 2012. 